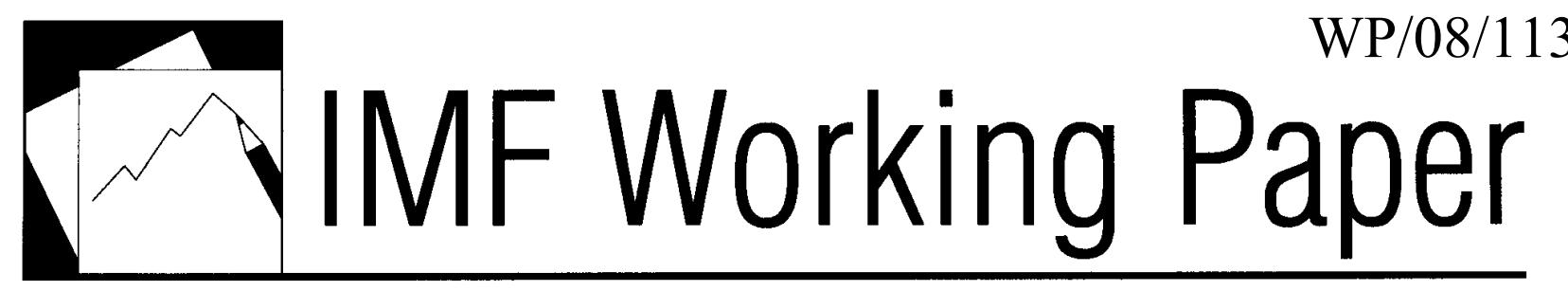

\title{
International Spillover of Labor Market Reforms
}

Mai Dao 



\title{
IMF Working Paper
}

European Department

International Spillover of Labor Market Reforms

Prepared by Mai Dao ${ }^{2}$

Authorized for distribution by Luc Everaert

April 2008

\begin{abstract}

\section{This Working Paper should not be reported as representing the views of the IMF.} The views expressed in this Working Paper are those of the author(s) and do not necessarily represent those of the IMF or IMF policy. Working Papers describe research in progress by the author(s) and are published to elicit comments and to further debate.

This paper uses a dynamic economy model, with unionized labor markets, to analyze the effects of labor market reforms, similar to those recently introduced in Germany, on the domestic and trading partner economies. The model is calibrated on Germany and the rest of the Euro area. The results indicate that German labor market reforms have positive spillover effects on the rest of the Euro area, which operate through the channel of trade, relative price adjustment, and financial market integration. Compared to a competitive labor market, setting, unionization dampens the positive response of the domestic economy and magnifies the spillover effects.
\end{abstract}

JEL Classification Numbers: F16, F42

Keywords: policy spillover, unionized labor markets, open economy model

Author's E-Mail Address:mcd2107@columbia.edu

\footnotetext{
${ }^{1}$ Department of Economics, Columbia University.

${ }^{2}$ I would like to thank Stefania Albanesi, Richard Clarida, John Donaldson, Chris Erceg, Luc Everaert, Edda Zoli as well as seminar participants at Columbia University and the IMF for their valuable comments and support. This paper was partly written while I was an intern in the Regional Studies division of the European Department, International Monetary Fund.
} 
I. Introduction 3

II. Model 4

A. Overview of Main Building Blocks ............................................................... 4

B. Final Goods Firms (F-firms) ..........................................................................

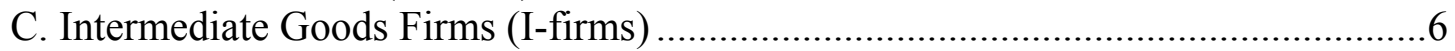

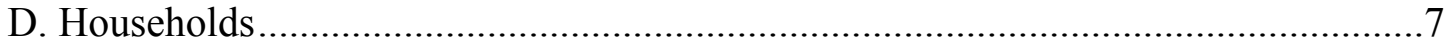

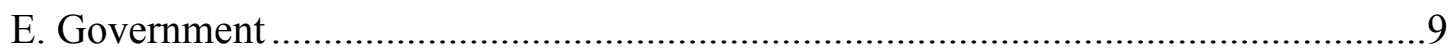

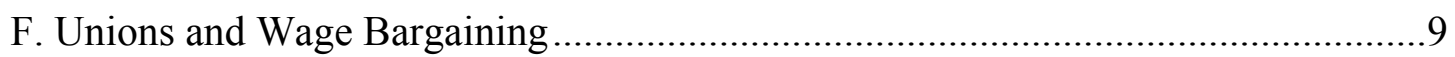

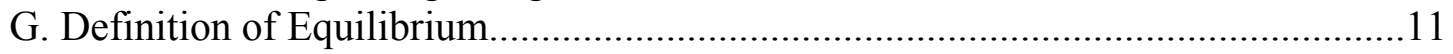

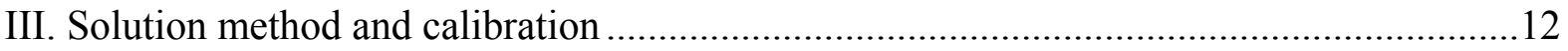

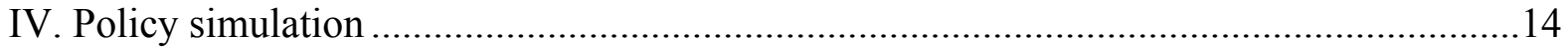

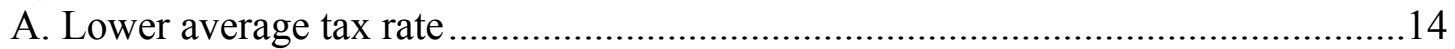

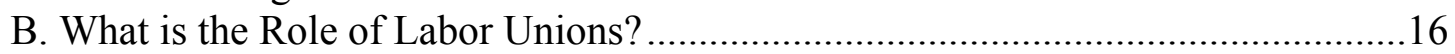

C. How Does Openness Affect Reform Outcome? .................................................... 17

D. Other Labor Market Reforms ............................................................................... 18

E. Relaxing the Perfect Financial Market Assumption............................................21

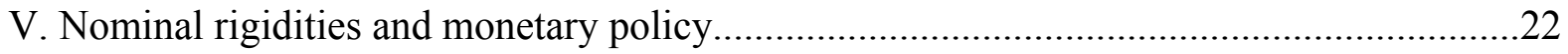

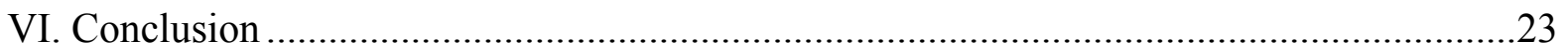

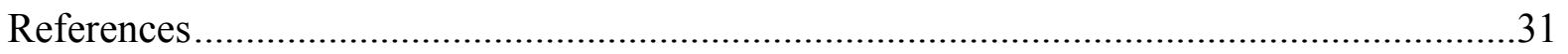

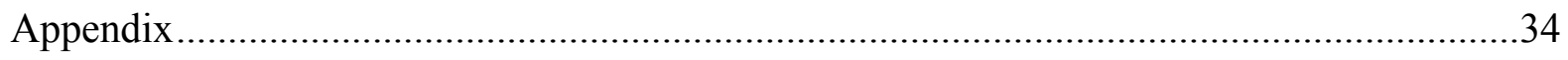

Tables

Table 1. Calibration of the Benchmark Model .................................................................. 14

Table 2: Long Term Effects of Policy Reforms, Percentage Deviation from Pre-reform.......19

Figures

Figure 1. Dynamic Responses of Domestic and Foreign Variables Following a Cut in Average Tax by $3 \%$, time in quarters ... 25

Figure 2a. Comparison of Response to $3 \%$ Tax Cut Under Unionized and Competitive Labor Market - output and absorption .....

Figure 2b. Comparison of Response to $3 \%$ Tax Cut Under Unionized and Competitive Labor Market - employment, wages and international trade

Figure 3. Response of Domestic and Foreign Variables to an Average Tax Cut of 3\% in Country 1, Under Benchmark and Completely Closed Economies. .28

Figure 4. Responses of Domestic and Foreign Variables to an Average Tax Cut of 3\% in Country 1, Under Benchmark and Incomplete Financial Markets

Figure 5. Responses of Domestic and Foreign Variables to an Average Tax Cut of 3\% in Country 1, Under Benchmark and Sticky Prices cum Monetary Union. 


\section{INTRODUCTION}

It is widely argued that the poor labor market performance in a number of European countries, especially in comparison to the United States, can be largely explained by regulatory institutions that create impediments to labor market participation and job creation. Therefore, in recent years, European countries have introduced reforms in the areas of labor taxation, labor regulation and welfare benefits (OECD, 2006). A notable example is Germany's so-called “Agenda 2010" reform of the welfare system, which is believed to have contributed to its latest economic recovery. The reform mostly aims at reducing unit labor costs and providing incentives for labor market participation. Given Germany's leading role in the regional economy, and its strong links with the rest of the Euro area, a natural question arises regarding the spillover effects of these policies on the other Euro members, the focus of this paper.

The issue of potential labor market policy spillovers is particularly relevant for Europe, where a debate is ongoing on whether European Union countries should coordinate their labor market and welfare policies, given the degree of integration of their product and financial markets (Bertola, 2006, 2007). Yet, there is very little understanding of the spillover mechanism, especially in the European institutional context. Using Vector Autoregressive (VAR) models, most existing studies estimate the cross-border effects of public consumption, operating through trade and the interest rate channel. ${ }^{3}$ But less is known on the cross-border effects of changes in distortionary taxation or welfare benefits, although the latter weigh more than public consumption in the government budget of industrialized countries.

To help fill this gap in the literature, we develop a two-country dynamic general equilibrium model, reflecting important features of European economies, and we use it to analyze the domestic and spillover effects of tax and welfare benefits reforms. We calibrate the model for Germany and the rest of the Euro area, using country specific data and available Bayesian estimates. The dynamic setting is important to trace out the macroeconomic response to tax changes over time. In fact, not only does it illustrate the prolonged adjustment path, but also shows that, in the presence of nominal rigidities and unionization, short-term effects can be qualitatively different from the long-term ones. Departing from the standard international real business cycle models, such as Backus, Kehoe, and Kydland (1994), we introduce a unionized labor market to better account for the reality of the European labor market. We assume that working hours are fixed, so that employment adjustment only takes place at the extensive margin, and that producers have price setting power through monopolistic competition. $^{4}$

\footnotetext{
${ }^{3}$ Two recent examples are Beetsma and others (2005) and Faini (2006).

${ }^{4}$ The model initially abstracts from other nominal and real frictions present in the rich class of new open economy macro models, such as Bayoumi, Laxton, and Pesenti (2004), in order to retain a simple framework to
}

(continued...) 
Simulation results suggest that German labor market reforms have positive spillover effects on the rest of the Euro area, and operate through the channel of trade, relative price adjustment and financial market integration. The existence of union bargaining turns out to be quantitatively, and sometimes qualitatively, decisive for the domestic response, as well as the spillover effects of the reforms. When the model is extended to incorporate price stickiness and a common monetary policy, the effect of inflation and monetary policy on the real interest rate provides an additional channel of spillover within the monetary union. It turns out that the short-term policy response is dampened in the domestic economy and magnified in the foreign economy by the existence of nominal frictions. However, the longterm responses of both economies are the same as under flexible prices.

The paper is organized as follows: The next section presents the building blocks of the model. Section 3 provides parameter calibration and the solution method. Section 4 shows simulation results from different policy experiments. Section 5 discusses some robustness checks. Section 6 introduces nominal rigidities, and section 7 concludes.

\section{MODEL}

The model builds on the framework of a standard two-country model such as Heathcote and Perri (2002) and Corsetti and Müller (2006).

\section{A. Overview of Main Building Blocks}

- $\quad$ The world consists of country 1 (Germany) and 2 (the rest of the Euro area), which are populated by a measure of $s$ and $1-s$ identical, infinitely lived households, respectively.

- In each country, there is a corresponding measure of producers of varieties of tradable intermediate goods. They act as monopolistic competitors in their pricing decisions. They use labor and capital as inputs, and sell their output to competitive final good producers, who bundle the domestic and foreign tradable goods into a composite nontradable consumption and investment good.

- Households participate in the labor market by membership in a firm-specific labor union. This union negotiates the real wage with the firm according to Nash bargaining. The firm then decides, given the wage outcome, its labor demand. Union members supply the labor demanded to the firm.

understand the main underlying channels of policy spillover in the presence of unions, which is the focus of this study. 
- $\quad$ The international financial market is perfect in the sense that there exists a complete set of state-contingent assets that can be traded within and across countries.

Households take advantage of this to insure each other of any income risk. ${ }^{5}$

- $\quad$ The government in each country runs a balanced budget by taxing labor income in a progressive manner, and providing flat unemployment benefits as well as lump sum transfers to the households.

\section{B. Final Goods Firms (F-firms)}

In each country, indexed by $i=1,2$, there is a continuum of firms operating in the TRADED intermediate sector $I$, and an equal measure of firms operating in the NON-TRADED final goods sector $F$. $I$-firms in country 1 produce differentiated varieties of good $a$, those in country 2 produce varieties of $b$. The representative final goods firm in each country buys the intermediate baskets $a$ and $b$ to produce the final NON-TRADED good for consumption and investment. $F$-firms in country $i$ maximize profits according to:

$$
\begin{gathered}
\max _{a_{i t}, b_{i t}}\left(f_{i t}-q_{i t}^{a} a_{i t}-q_{i t}^{b} b_{i t}\right) i=1,2 \\
f_{1 t}=\left[\omega_{1}^{1 / \sigma} a_{1 t}^{(\sigma-1) / \sigma}+\left(1-\omega_{1}\right)^{1 / \sigma} b_{1 t}^{(\sigma-1) / \sigma}\right]^{\sigma /(\sigma-1)} \\
f_{2 t}=\left[\left(1-\omega_{2}\right)^{1 / \sigma} a_{2 t}^{(\sigma-1) / \sigma}+\omega_{2}^{1 / \sigma} b_{2 t}^{(\sigma-1) / \sigma}\right]^{\sigma /(\sigma-1)}
\end{gathered}
$$

Where $q_{i t}^{a}\left(q_{i t}^{b}\right)$ is the price index of intermediate good $a(b)$ in country $i$ in terms of its final good; $\sigma$ is the elasticity of substitution between the intermediate goods, and $\omega_{1}, \omega_{2}>0.5$ reflects the extent of home bias in private consumption and investment. In the following, we present variables for country 1 , and ignore the time index unless necessary. Variables for country 2 are equivalent. The baskets $a_{1}$ and $b_{1}$ are CES indexes of intermediate tradable varieties $h \in[0, s]$ produced in country 1 and varieties $f \in[s, 1]$ imported from country 2 :

$$
\begin{gathered}
a_{1}=\left[\left(\frac{1}{s}\right)^{\frac{1}{\eta}} \int_{0}^{s} a_{1}(h)^{1-\frac{1}{\eta}} d h\right]^{\frac{\eta}{\eta-1}} \\
b_{1}=\left[\left(\frac{1}{1-s}\right)^{\frac{1}{\eta}} \int_{s}^{1-s} b_{1}(f)^{1-\frac{1}{\eta}} d f\right]^{\frac{\eta}{\eta-1}}
\end{gathered}
$$

\footnotetext{
${ }^{5}$ This assumption is made for simplicity. As shown later, assuming imperfect financial markets hardly changes the results.
} 
where $\eta$ is the elasticity of substitution across varieties in each basket. Denoting the price of intermediate varieties, also in terms of home final goods as $q_{1}^{a}(h)$ and $q_{1}^{b}(f)$, we get the final producer's optimal demand for each variety as:

$$
\begin{aligned}
& a_{1}(h)=\left(\frac{q_{1}^{a}(h)}{q_{1}^{a}}\right)^{-\eta}\left(q_{1}^{a}\right)^{-\sigma} \frac{\omega}{s} f_{1} \\
& b_{1}(f)=\left(\frac{q_{1}^{b}(f)}{q_{1}^{b}}\right)^{-\eta}\left(q_{1}^{b}\right)^{-\sigma} \frac{(1-\omega)}{s} f_{1}
\end{aligned}
$$

where the consumption based price indices are

$$
q_{1}^{a}=\left[\frac{1}{s} \int_{0}^{s} q_{1}^{a}(h)^{1-\eta} d h\right]^{\frac{1}{1-\eta}}, \quad q_{1}^{b}=\left[\frac{1}{1-s} \int_{s}^{1} q_{1}^{b}(f)^{1-\eta} d f\right]^{\frac{1}{1-\eta}}
$$

\section{Intermediate Goods Firms (I-firms)}

A representative intermediate $I$-firm in country 1 maximizes profits according to:

$$
\max _{q_{1}^{a}(h), K_{1}, n_{1}} \Pi_{1}=\left(q_{1}^{a}(h)\left(a_{1}(h)+a_{2}(h)\right)-w_{1} n_{1}-r_{1} K_{1}\right)
$$

using the standard Cobb-Douglas production function:

$$
Y_{1}(h)=a_{1}(h)+a_{2}(h)=e^{z_{1}} K_{1}(h)^{\theta} n_{1}(h)^{1-\theta}
$$

and taking into account the demand functions in (1). The level of total factor productivity $e^{z}$ is set at 1 in the following to abstract from technological shocks.

With flexible prices, all firms set the relative price as a mark-up over real marginal costs $\xi_{1}$ (defined below)

$$
q_{1}^{a}=\frac{\eta}{\eta-1} \xi_{1}
$$

and furthermore demand factor input to minimize costs according to:

$$
\xi_{1} \frac{\partial Y_{1}}{\partial n_{1}}=\xi_{1}(1-\theta) \frac{Y_{1}}{n_{1}}=w_{1}
$$




$$
\xi_{1} \frac{\partial Y_{1}}{\partial K_{1}}=\xi_{1} \theta \frac{Y_{1}}{K_{1}}=r_{1},
$$

$\xi_{1}$, the real marginal costs (in terms of the final good), are given by

$$
\xi_{1}=w_{1}{ }^{1-\theta} r_{1}{ }^{\theta} \theta^{-\theta}(1-\theta)^{\theta-1}
$$

Producers of intermediate goods in country 2 solve a similar problem. The monopolistic competition structure is chosen so that firms have some rent entering the wage bargaining process. Choosing the present product market structure also facilitates the extension to sticky prices. With a competitive product market and a monopolistic union, the qualitative results of the paper do not change.

\section{Households}

In country 1 , there is a continuum of symmetric, infinitely lived households of measure $s$. Aggregating over households, we get the aggregate discounted lifetime expected utility as:

$$
E_{0} \sum_{t=0}^{\infty} \beta^{t}\left[\frac{C_{1 t}{ }^{1-\mu}}{1-\mu}-\Gamma n_{1 t}\right]
$$

Here, ${ }^{n}{ }_{1}$ stands for the fraction of time spent working, or the employment rate in the economy. The linear disutility of labor is a consequence of the assumption of indivisible labor. In fact, when households can only choose to work a fixed number of hours, or not at all, the resulting aggregate preference is always linear in the fraction of time, or probability or working (Hansen, 1984). This means that the intertemporal elasticity of substitution of labor is infinite, no matter how small this elasticity is for the individual household. This preference specification has often been shown to better replicate the fluctuation of labor hours along the business cycle, and offers a natural setting to compare the competitive with the unionized labor market specification. ${ }^{6}$

We take the asset market to be complete so that there exists a set of traded state-contingent securities that span all events $s_{t} \in S$ for each period $t$. Denote the history of events up to, and including period $t$, as $s^{t}$, then at every period $t$ with history $s^{t}$, the household is subject to the following budget constraint:

$C_{1 t}+I_{1 t}+q_{1 t}^{a} E_{t} Q_{t, t+1} A_{1, t+1}\left(s^{t}, s_{t+1}\right)=n_{1 t} w_{1 t}\left(1-\tau_{1 t}\right)+r_{1 t} K_{1 t}+T R_{1 t}+\Pi_{1 t}+\left(1-n_{1 t}\right) U B_{1 t}+q_{1 t}^{a} A_{1 t}\left(s^{t-1}, s_{t}\right)$ and accumulates capital subject to the following law of motion:

$$
K_{1, t+1}=(1-\delta) K_{1 t}+I_{1 t}-\frac{\phi_{k}}{2}\left(\frac{K_{1 t+1}}{K_{1 t}}-1\right)^{2} K_{1 t}
$$

\footnotetext{
${ }^{6}$ See Zanetti (2007) for a recent application of a union model to study European business cycles.
} 
The parameter ${ }^{\phi} k$ represents the degree of capital adjustment costs and $\delta$ the depreciation rate. Each variable in period $t$ is understood to depend on the state $s^{t}$. Expressions on the right hand side of the budget constraint denote, respectively, the household income from labor, capital, transfers from the government, profit rebated by firms, and unemployment benefits. $A_{t+1}\left(s^{t}, s_{t+1}\right)$ is the quantity of Arrow-Debreu securities bought after history $s^{t}$ that pays one unit of good $a$ (arbitrary numeraire) if and only if state $s_{t+1}$ occurs in $t+1$;

$Q_{t, t+1}=Q\left(s^{t}, s_{t+1}\right)$ denotes the state contingent stochastic discount factor used to price the security. Labor income is taxed at the average rate $\tau$, while unemployed individuals receive flat unemployment benefits $U B$.

We solve the model both under competitive and unionized setting. Under a competitive labor market, the household chooses the optimal path for consumption, investment, asset holding and employment probability, taking wages, prices and all policy variables as given. The first order conditions (FOCs) for each point in time and state is given by:

$$
\begin{aligned}
C_{1 t}^{-\mu} & =\lambda_{1 t} \\
\Gamma & =\lambda_{1 t}\left[\left(1-\tau_{1 t}\right) w_{1 t}-U B_{1 t}\right] \\
\lambda_{1 t} & =\beta E_{t}\left[\lambda_{1 t+1}\left(1-\delta+r_{1 t+1}\right)\right] \\
Q_{t, t+1} & =\beta \frac{\lambda_{t+1} q_{1, t+1}^{a}}{\lambda_{t} q_{1, t}^{a}}
\end{aligned}
$$

In country 2 , the FOCs are equivalent. In particular, as the FOC (3d) with respect to statecontingent asset holding in country 2 yields the same value for the stochastic discount factor, we obtain the following international risk-sharing condition:

$$
\lambda_{1 t} q_{1 t}^{a}=\kappa \lambda_{2 t} q_{2 t}^{a}
$$

where $\kappa$ is a constant depending on the given initial distribution of wealth. This risk-sharing condition implies that, given the possibility of trading in a complete set of state-contingent assets, households within and across countries will optimally choose to equalize their marginal utility of consumption measured in terms of good $a$ (up to a constant). Under a unionized labor market, as we discuss below, the labor supply FOC ( $3 \mathrm{~b}$ ) will be replaced by a wage setting equation determined by unions. In that case, the labor decision is completely dissociated from the consumption decision and only determined by unions and firms. The other FOCs hold for both labor market specifications. 


\section{E. Government}

In every period, the government in each country taxes labor income at average rate $\tau$ to finance unemployment benefits $U B$ per unemployed worker, and provides lump sum transfers $T R$ to the households. The balanced budget constraint is:

$$
\tau_{t} w_{t} n_{t}=T R_{t}+\left(1-n_{t}\right) U B_{t}
$$

The tax rate can be further decomposed into a lump sum tax allowance $A$, and a marginal rate $t$, so that tax payment $T$ is progressive with income:

$$
\tau \equiv \frac{T}{w}=\frac{t(w-A)}{w}=t-\frac{A t}{w}<t
$$

In other words, due to the wedge between the average and marginal tax rate, following an increase of one percent in pre-tax income, net income increases by less than one percent. The flat unemployment benefits assumption does not reflect the complex unemployment benefits scheme of most OECD countries, as initial benefit levels depend in some way on previous labor income. However, unemployment insurance in the form of income replacement only occurs for a limited period of time, and only after a considerable period of insured employment. Thus, most unemployed workers are only entitled to a minimum unemployment assistance that is fixed in real terms (OECD, 2004).

\section{F. Unions and Wage Bargaining}

Workers in each country are organized into firm-specific trade unions. The wage is determined through bargaining between each union and firm, taking all other aggregate variables, in particular the policy variables and wages set by other unions/firms, as given. The firm keeps the 'right-to-manage' by setting unilaterally the employment level after the wage has been negotiated. The households, then, supply the labor demanded. This union wage bargaining set-up is similar to Pissarides (1998) and represents a more general specification than the monopoly union model used in other Dynamic Sthocastic Genarel Equilibrium (DSGE) models, such as Maffezzoli (2001) and Ardagna (2007). Unions are assumed to be risk neutral, i.e. they only care about the average net surplus of their members. ${ }^{7}$ For each bargaining party, the relative bargaining power is given by $p$ and $1-p$ respectively. For a typical union-firm $j$ in country 1 , the Nash bargaining problem can be represented as:

$$
\max _{w} S_{j}{ }^{p} \Pi_{j}{ }^{1-p} \text { s.t. } \frac{\partial \Pi_{j}}{\partial n_{j}}=0, \quad j \in[0, s]
$$

where the union surplus is:

\footnotetext{
${ }^{7}$ Introducing risk averse unions does not change the model's main results. Also, having unions operate at the sectoral level does not change the results, as long as unions do not internalize the aggregate effect of their behavior.
} 


$$
S_{j}=n_{j}\left[(1-\tau) w_{j}-\hat{w}\right]
$$

and the outside option $\hat{w}$ is equal the income if not employed in firm $j$. In that case, it is assumed that these workers find a job elsewhere in the economy with a positive probability equal to the economy-wide employment rate, and if not, receive unemployment benefits. Hence, denoting the average wage set in the economy by $w$, we have:

$$
\hat{w}=n(1-\tau) w+(1-n) B
$$

The outside option for the firm is zero profit. Thus, the firm's bargaining surplus equals its profit function $\Pi$ given by equation (2). The FOC for the bargaining problem can be written as:

$$
p \frac{\partial S}{\partial w} * \frac{w}{S}+(1-p) \frac{\partial \Pi}{\partial w} * \frac{w}{\Pi}=p \varepsilon_{S}+(1-p) \varepsilon_{\Pi}=0, \varepsilon_{\Pi}<0<\varepsilon_{S}
$$

Here, ${ }^{\varepsilon_{s}}$ stands for the elasticity of the union's surplus with respect to wages and ${ }^{\varepsilon_{\Pi}}$ stands for the (negative) elasticity of the firm's profit with respect to wages. At the optimal wage, the weighted elasticity of the union surplus must equal the weighted elasticity of the firm's profit with respect to the wage, where the weights are given by the relative bargaining powers. Each union and firm is small relative to the rest of the economy, and hence takes the aggregate variables as given. Yet, in a symmetric equilibrium, all unions and firms choose the same wage which is a mark-up over the unemployment benefits:

$$
w=\left[(1-\tau)-\frac{p \theta(1-t)}{(1-n)[p+(1-p)(\eta-1) \theta(1-\theta)]}\right]^{-1} U B
$$

The following comparative static observations concerning the mark-up can be made:

- $\quad$ The higher the pure average tax rate $\tau$, the higher the bargained wage. Although taxes are levied on workers, they are completely borne by firms since unions are able to shift them via higher wage demands, implying higher labor costs (Alesina and Perotti, 1997).

- $\quad$ Rather surprisingly, a higher marginal tax rate $t$ (at constant average rate) will have a negative effect on the equilibrium wage. This wage moderating effect of progressive taxation is well-known in the literature, (see Pissarides, 1998; van der Ploeg, 2006, for theoretical derivation; and Lockwood and Manning, 1993; Schneider, 2005, for some empirical evidence). The reason is the following. Unions maximize both the after-tax wage and employment, while firms only base their hiring decisions on the pre-tax wage. With higher progressivity, a given after-tax wage will require a higher pre-tax wage and hence will be more costly in terms of employment loss. This negative substitution effect will make unions find it optimal to accept lower pre-tax wages in exchange for higher employment instead. 
- In plausible ranges of parameter values, wage outcomes are higher, the higher the relative bargaining power of unions. ${ }^{8}$

- The higher the economy-wide unemployment rate $(1-n)$, the lower the wage. Higher unemployment implies a lower chance of finding a job elsewhere, and a less attractive outside option for union members, resulting in more moderate wage requests.

- $\quad$ The higher the market power of producers (i.e. the lower $\eta$ ), the higher the wage. As higher market power allows firms to pass more of the labor costs on prices, unions will take advantage of this, and demand higher wages. A reform targeting a reduction in firms' market power would have a wage moderating effect.

- $\quad$ Finally, the higher the capital share, i.e. the higher $\theta$, the higher the wage. A high capital share, or a low labor share, makes firms' overall marginal costs less sensitive to wage changes. This leaves more space for negotiation and, ceteris paribus, leads to a higher wage outcome.

The wage setting equation (4) will be important to assess the effect of policy reform on the economy. Any policy that reduces unemployment benefits, or the mark-up, will create higher employment and, hence, more output. ${ }^{9}$ It is worth mentioning that our framework of labor market imperfection in the form of unionization differs from the common model of workers' exogenous wage-setting power (e.g. Erceg et al., 2002). First, instead of assuming an exogenous mark-up, we are able to derive an explicit wage bargaining problem, and an endogenous mark-up factor. Second, while models with an exogenous mark-up still link labor supply to the marginal rate of substitution between consumption and leisure, our model departs from this by assuming that wage setting is a collective decision and, hence, not related to individual leisure preference. ${ }^{10}$ This feature of the model has important implication for policy and spillover effects, as discussed later.

\section{G. Definition of Equilibrium}

The competitive equilibrium of the economy is characterized by a set of state-contingent path of prices $\left\{w_{i t}, q_{i t}^{a}, q_{i t}^{b}, r_{i t} \mid s^{t}\right\}_{t=0}^{\infty}$ for $i=1,2$ such that:

- Households solve their consumption/investment problem.

\footnotetext{
${ }^{8}$ This parameter is hard to pin down a priori, since it is implicitly defined by institutional regulations. A discussion of the calibration for this is given in Section 3.

${ }^{9}$ Our analysis only focuses on the demand side of labor, and abstracts from any effect of policy on labor supply that is amply analyzed elsewhere.

${ }^{10}$ This does not mean that unions do not value leisure. In fact, utility from leisure can be incorporated in the outside option of the union, without changing the results. The distinction is between individual labor supply decision and collective strategic bargaining.
} 
- $\quad F$-firms solve their production problem.

- $\quad I$-firms solve their price setting and production problem.

- Unions and firms solve the wage bargaining problem.

- $\quad$ Governments balance their budget.

- $\quad$ All markets clear, i.e. in terms of per capita variables:

$$
\begin{gathered}
a_{1 t}+\frac{1-s}{s} a_{2 t}=Y_{1 t} \\
\frac{s}{1-s} b_{1 t}+b_{2 t}=Y_{2 t} \\
C_{1 t}+I_{1 t}=f_{1 t} \\
C_{2 t}+I_{2 t}=f_{2 t}
\end{gathered}
$$

The equilibrium will further yield implications for the following variables, which are of interest for international transmission mechanism:

- Terms of trade

$$
T o T_{t}=\frac{\mathrm{P}_{\mathrm{Im}}}{P_{E x}}=q_{1 t}^{b} / q_{1 t}^{a}
$$

- Real exchange rate $R X R_{t}=q_{1 t}^{a} / q_{2 t}^{a}=q_{1 t}^{b} / q_{2 t}^{b}$

- Net exports/GDP ratio (of country 1) $n x_{1 t}=\left(q_{1 t}^{a} a_{2 t}-q_{1 t}^{b} b_{1 t}\right) / q_{1 t}^{a} Y_{1 t}$

Note that with this notational convention, an increase in $T o T$ or $R X R$ means a terms of trade deterioration, or a depreciation of country 1 goods relative to country 2 , respectively.

\section{SOLUTION METHOD AND CALIBRATION}

To solve the model, we log-linearize the FOCs for households, firms, and unions around the initial balanced trade steady state, and impose market clearing and government budget balance. This yields 35 expectational difference equations in 35 unknowns that we solve with the method of Blanchard and Kahn (1980), using the Anderson and Moor (1985) numeric algorithm.

The choice of parameter values is an important element, affecting the magnitude of propagation and spillovers from policy reforms in Germany to the rest of the Euro area. Table 1 shows the calibrated values at quarterly frequency. Where possible, values are taken 
from recent estimation of similar DSGE models for the Euro area. The first block of parameters is identical for both countries, while the second one is country specific.

The time preference and depreciation rate parameters are standard, and imply a steady state real interest rate of four percent, and an annual capital depreciation rate of ten percent. Consistent with a number of empirical studies, the capital share parameter is set at 0.45 . The intertemporal elasticity of substitution parameter is obtained from standard micro evidence, and available estimates for the Euro area (Lubik and Schorfheide, 2005). Existing calibrations for the price mark-up range from 1.1 (Chari, Kehoe, McGrattan, 2002) to 1.35 (Bayoumi, Laxton, Pesenti, 2004). We choose an intermediate value of 1.21 , which corresponds to an elasticity of substitution $\eta$ of 5.8. A key variable for the spillover mechanism is the elasticity of substitution between foreign and domestic intermediate goods $(\sigma)$, which we set equal to 1.5, consistent with several macroeconomic studies (e.g., Corsetti and Müller, 2006, and Arvanitis and Mikkola, 1996). ${ }^{11}$ Given the importance of this parameter for the spillover effects, we later perform sensitivity analysis with it. The capital adjustment cost parameter $\varphi$ is set at 10, following estimates for the Euro area by Langedijk and Roeger (2007). This value is rather arbitrary, but its variation hardly affects the dynamics of the main variables.

The size of the German economy relative to the rest of the Euro area is calibrated by the relative population size. The import share of Euro area traded goods to German GDP, as well as German traded goods relative to rest of Euro area GDP, are calculated from 2006 trade data from the German Federal Statistical Office. Benchmark levels of the effective average and marginal tax rates on labor and the gross replacement rates ( $g r r$ ) are as of 2004, and taken from OECD $(2004,2006)$.

The institutional bargaining power parameter $p$ poses some challenge as it is not directly observable, and its calibration is very model dependent. However, given the model's remaining parameters, and the steady state employment rate, we can solve for the implied value of $p$ as:

$$
p=(\sigma-1)(1-\theta)\left[\frac{1-t}{(1-n)(1-\tau-g r r)}-\frac{1}{\theta}+(\sigma-1)(1-\theta)\right]^{-1}
$$

The model implied value is $p=0.59$ for Germany, and $p=0.49$ for the rest of the Euro area. Interestingly, these values almost coincide with other estimates of a proxy of union power

\footnotetext{
${ }^{11}$ There is a wide range of estimates for this parameter, from as low as 0.4 in Lubik and Schorfheide (2005) to as high as 5 in Langedijk and Roeger (2007). Studies that use values higher than 1.5 usually incorporate adjustment costs in import demand (e.g., Erceg et al., 2005).
} 
(Dumont et al., 2006; and Botero et al., 2004). ${ }^{12}$ This is reassuring in terms of model consistency with actual data.

Table 1. Calibration of the Benchmark Model

$\begin{array}{lcc}\text { Parameter } & \text { Germany } & \text { EU11 } \\ \text { Discount factor } \beta & .99 & .99 \\ \text { Depreciation rate } \delta & .025 & .025 \\ \text { Capital share } \theta & .45 & .45 \\ \text { Intertemp. elast. subst. } \mu & 2.5 & 2.5 \\ \text { Intratemp. elast. subst. }{ }^{*} \eta & 5.8 & 5.8 \\ \text { Intratemp. elast. subst.** } \sigma & 1.5 & 1.5 \\ \text { Capital adjustment cost } \varphi & 10 & 10 \\ & & \\ \text { Population share } s / 1-s & -275 & .725 \\ \text { Employment rate } n & .65 & .63 \\ \text { Import share }\left({ }^{1-w_{d}} \text { ) }\right. & .13 & .07 \\ \text { Average tax rate } \tau & .33 & .22 \\ \text { Marginal tax rate } t & .54 & .36 \\ \text { Gross replacement rate } g r r & .29 & .36 \\ \text { Union bargaining power } p & .59 & .49 \\ \quad * \text { across domestic varieties, } & * * \text { across traded goods }\end{array}$

\section{Policy Simulation}

\section{A. Lower average tax rate}

In the following, we simulate the model-implied dynamic responses to different policy shocks originating from country 1 , in an attempt to mimic the labor market reforms carried out in Germany during 2000-2005. ${ }^{13}$ The first policy experiment is an increase in the lump

\footnotetext{
${ }^{12}$ Dumont et al.'s (2006) estimates are based on two-digit level manufacturing sectors data, and imply a union power parameter of $p=0.597$ for Germany, and an average $p=0.494$ for Belgium, France and Italy. Botero et al (2004) construct and estimate an index of what they call "collective relations law", which integrates data on all legal aspects determining the balance of power between labor unions and employment associations, as well as laws governing collective disputes (strikes). For Germany, the computed index is 0.607 , and the average of ten Euro area countries is 0.505 .

${ }^{13}$ For details, see German Federal Ministry of Finance, at: http://www.bundesfinanzministerium.de/cln_05/nn_4248/DE/Steuern/Steuerreform/
} 
sum tax allowance, with an unchanged marginal tax rate ${ }^{14}$, leading to a 3 percent decline in the average tax rate, financed by an adjustment in lump sum transfers to households. ${ }^{15}$ Simulation paths under perfect foresight, are given in Figure 1. The phase-in period is set at 5 years to mimic the pace of tax reform in Germany. The left column shows the response of the domestic economy (Germany), while the right column shows the spillover effect on the aggregate variables of the foreign (rest of the Euro area) economy.

The impulse for the domestic response comes mostly from the labor market. On impact, the real wage requested by unions decreases, leading to a surge in labor demand and employment. For a given capital stock, the lower wage and higher employment increase the return to capital, triggering a rise in investment. As capital is accumulated, labor becomes more productive. This allows firms both to increase employment, and accept gradually higher wages, even before the anticipated tax reform is completed. The increase in both production factors leads to higher output. As for consumption, the decrease in the tax rate generates a positive wealth effect on impact.

As production of the home good expands, home terms of trade deteriorates, and the real exchange rate depreciates. Gradually, these developments depress the real returns to investment, which counteracts the positive effect from higher employment and hence, reinforces the decrease of the real interest rate. This channel of feedback from the terms of trade on the domestic economy is stronger the more open the economy is, i.e., the smaller the home bias. As for the trade balance, there are two opposing effects: the real trade balance improves for country 1 following the real depreciation. However, the unfavorable terms of trade development has a negative effect on the value of the trade balance. With the chosen calibration for the elasticity of substitution between traded goods, the former effect dominates and the trade balance registers a surplus compared to the baseline. This is consistent with the trade balance improvement experienced by Germany in the post-reform period. The response of the trade balance is crucially determined by the elasticity of substitution. In particular, it can move into deficit for a sufficiently low value of this parameter, i.e., if consumers do not substitute sufficiently following a relative price change. ${ }^{16}$

For country 2, one can identify two channels of transmission. The first channel is trade. Country 1's terms of trade deterioration favors investment in the country 2. As a result, both capital and labor productivity, measured in consumption units, increase for any given level of input. In the labor market, this allows unions to bargain for a higher wage and higher

\footnotetext{
${ }^{14}$ In this experiment we keep the marginal tax rate constant to focus on the effect of lower average tax rates.

${ }^{15}$ These lump sum transfers/taxes can be interpreted as a surplus/deficit of the government budget (Baxter, 1995).

${ }^{16}$ Some sensitivity analysis is presented in the Appendix.
} 
employment. As employment increases, so does the return to capital, encouraging capital accumulation. This expansion eventually leads to higher output in country 2 , supported by the positive wealth effect from the favorable terms of trade and increased import demand from country 1 .

The second channel of transmission is through the financial market. Since consumers in both countries insure each other completely, the foreign country shares the increase in home income through its asset pay-outs. Therefore, consumption in country 2 increases more than output, reinforcing the positive wealth effect of the terms of trade described above.

In sum, spillover effects are positive and most pronounced for consumption, due to the financial market linkage and terms of trade effects, and least pronounced for employment and output. The reason for the modest spillover on employment is that, unlike in the home country, where the tax decrease leads to a decline in wage demand, wages in the foreign country increase following the tax cut in country 1 , due to the higher terms of trade. Therefore, although labor demand shifts up, it does so much less than in country 1 . This implies that country 1's reform generates asymmetric welfare effects.

\section{B. What is the Role of Labor Unions?}

Since a crucial aspect of this paper is to analyze how the institution of labor unionization affects the economy's response to policy shocks, we carry out the same simulations assuming competitive labor markets. In this setting, instead of bargaining, households decide on labor supply at the extensive margin given the wage, while firms optimize their labor demand as before. Dynamic responses under both unionized and competitive labor markets are presented in Figure 2.

Having a competitive labor market with indivisible labor, or very highly elastic labor supply, makes employment highly sensitive to any policy influencing the wage, in line with standard results from the literature (Prescott, 2004). Consequently, an average tax cut of 3 percent raises employment by 1.2 percent on impact, and 5.6 percent in the long run. Under a unionized setting, the positive employment impact amounts to only 0.7 percent on impact, and 2.5 percent in the long run. Also, the dynamic response of domestic output, consumption and investment is qualitatively the same, yet quantitatively much more dampened under a unionized than under a competitive labor market. In fact, under a competitive labor market, domestic quantities react more than twice as much as under a unionized market in the long run.

This underlines the importance of labor market structure in understanding the policy propagation mechanism. The reason for this is the following: In the competitive market, households decide on optimal labor supply. A decrease in the tax rate increases households' labor supply via the consumption-leisure substitution effect. Higher labor supply, then, reduces the pre-tax wage that firms have to pay, thus boosting labor demand. In the new 
equilibrium, employment is higher, labor costs (pre-tax wage) are lower, and net wages are higher, as wages decrease less than taxes. With union bargaining, however, workers are able to extract some collective rent instead of adjusting their labor supply individually. Lower taxes let them demand lower wages, but not as low as the competitive wage. In fact, along a positive sloping contract curve, expectation of higher employment also creates an upward pressure on wages, according to equation (4), making the net effect less negative than under the competitive case. With wages falling less, labor demand increases less, and so do other aggregate variables following the tax reform.

As for the spillover effects on country 2, results differ significantly under the two labor market structures. This is first due to the higher terms of trade deterioration that the larger expansion of home output brings about under competitive labor markets. A higher terms of trade deterioration leads to greater substitution to country 1 goods, decreasing output in country 2. This generates an even higher trade surplus for country 1 . Moreover, the positive wealth effect triggered by the terms of trade reduces labor supply in country 2 , which has a further negative impact on output and employment. The negative substitution and the positive wealth effect therefore cause output, employment and investment to fall on impact and in the long run in country 2 . The positive wealth effect from higher terms of trade and risk sharing through financial market still results in higher consumption. But the stronger terms of trade appreciation (for country 2) entails a greater wealth effect and a sharper increase in consumption. Note also that the asymmetric wage development across countries still obtains in the competitive case. In fact, it is even reinforced through lower labor supply.

To sum up, compared with a competitive labor market, the existence of union bargaining, and its influence on the labor market outcome, strongly dampens the domestic economy's response to a policy shock. It also qualitatively reverses the spillover effect on the foreign economy in the sense that a smaller country 1's terms of trade deterioration, and the absence of a wealth effect on labor supply, lead to an expansion, instead of a contraction, in foreign output and employment. In assessing the global implications of a policy reform, it is therefore crucial to specify the appropriate labor market structure.

\section{How Does Openness Affect Reform Outcome?}

Trade openness is commonly regarded as a key factor determining the strength of any spillover effect. It is therefore interesting to analyze how the degree of openness affects the domestic and cross-border effects of policy reforms. In the present model, the parameter measuring the degree of trade openness is the home bias parameter $\omega$ in final consumption and investment. To compare two extremes, Figure 3 shows the effects of the same reduction in the average tax rate in the baseline model and in the case where both countries are completely closed economies ( $\omega_{1}$ and $\omega_{2}$ are set to equal one, and there is no risk sharing).

Except for consumption, openness hardly affects the domestic response to the tax reform in country 1, consistent with findings by Erceg et al. (2007). Consumption increases more than 
in the open economy case, due to the absence of risk sharing and the negative wealth effect from the terms of trade deterioration. Only consumers in country 1 benefit from the positive supply shock. The domestic demand increase completely makes up for the absence of export demand, so that output (as well as employment and investment) react almost the same as under the open economy scenario. In the short run, as high domestic demand drives up the real interest rate more than in the open economy case, investment decreases on impact, and rises gradually as capital gets more productive with higher labor input. Overall, we can conclude that openness hardly affects the domestic response to the tax reform, consistent with findings by Erceg et al. (2007).

As for country 2, the most noticeable difference is the lack of a rise in consumption due to the absence of risk sharing and terms of trade appreciation. All other variables do not react. However, since the spillover under open economy was only weakly positive for all variables except consumption, we can conclude that openness does not matter dramatically for the spillover effects either. In fact, the difference in domestic and spillover effects under the different labor market specifications (Figure 2a, b) are much more pronounced than under different degrees of openness.

In sum, contrary to the common belief, trade openness is not the most important determinant for the transmission of fiscal shocks. Instead, the degree of labor market competitiveness matters much more for the transmission effect on the foreign country.

\section{Other Labor Market Reforms}

Since a given change in the overall tax wedge can have differential economic effects depending on the underlying composition of marginal and average tax changes, this section discusses the long-run effects of three other labor market reforms, which also mimic policy measures recently introduced in Germany (Table 2):

- A 2 percent reduction in the marginal tax rate, with a corresponding decrease in the lump sum tax allowance to keep the average tax rate unchanged. In Germany the marginal tax rate facing the average production worker fell by roughly 2 percent over 2000-2005. We assume the compensating decrease in tax allowance to analyze the contribution of the pure marginal rate decrease.

- A reduction in flat unemployment benefits. The German Hartz IV welfare reform package cut the duration and the level of benefits to reduce the disincentives to work. Our model allows the assessment of the impact of the reform through the labor costs channel. In our stylized setting, we assume an average income loss for a benefit dependent household of 7.42 percent, consistent with a study by Blos and Rudolph (2005). 
- A reduction in union bargaining power, consistent with the recent movement toward lower union density, more decentralized wage-setting, and greater use of optout clauses observed in Germany and other OECD countries. ${ }^{17}$ We assume a scenario where union bargaining power in Germany is reduced from 0.59 to the rest of the Euro area level (0.49).

Table 2: Long Term Effects of Policy Reforms, Percentage Deviation from Pre-reform Steady State (benchmark model)
Baseline: $\Delta \tau=-3 \%$
1) $\Delta t=-2 \%$
2) $\Delta B=-7.42 \%$
3) $\Delta p=-10 \%$

\begin{tabular}{lcccc}
\hline Domestic: & & & & \\
Output & 2.18 & -1.19 & 1.56 & 4.37 \\
Consumption & 1.07 & -0.58 & 0.77 & 2.14 \\
Employment & 2.54 & -1.39 & 1.82 & 5.11 \\
Investment & 1.73 & -0.95 & 1.24 & 3.47 \\
Real wage & -0.81 & 0.44 & -0.58 & -1.63 \\
\hline Foreign: & & & & \\
Output & 0.24 & -0.13 & & 0.17 \\
Consumption & 0.66 & -0.36 & 0.47 & 1.32 \\
Employment & 0.10 & -0.05 & 0.07 & 0.19 \\
Investment & 0.41 & -0.22 & 0.29 & 0.81 \\
Real wage & 0.31 & -0.17 & 0.22 & 0.62 \\
& & & & 3.30 \\
ToT & 1.64 & -0.90 & 1.18 & 0.90 \\
Trade balance & 0.45 & -0.25 & 0.32 & \\
(net export/GDP in 1$)$ & & &
\end{tabular}

In contrast to the baseline scenario of a cut in average tax rate, a lower marginal tax rate (Scenario 1) encourages a more aggressive wage bargaining by unions and hence, leads to a higher wage outcome than that derived in Section 4. The resulting response of the economy is negative in both countries. Therefore, a tax reform as the one in Germany, which envisages a reduction of both the average and marginal tax rate, has two inherently opposing effects on the wage bargaining outcome and employment. However, as long as the tax allowance is

\footnotetext{
${ }^{17}$ See OECD (2006), Chapter 3.
} 
increased at the same time, such that the average tax decrease is larger than the marginal, the positive effect dominates. This holds for the effects on the domestic as well as the foreign economy. It is important to stress that this is valid under the model's assumption of exogenous labor supply and involuntary unemployment. Thus, a cut in marginal tax that increases labor supply can still be desirable to increase labor market participation.

The positive effect of lower unemployment benefits operates through a reduction in the union members' outside option. All domestic propagation and international spillover mechanisms are the same as in the case of a tax cut in the baseline scenario. The experiment of a reduction in union bargaining power suggests that the economic cost of powerful unions is very large. A decline in the union power to the average level of the rest of the Euro area would increase long-run employment and output in Germany by more than 5 and 4 percent, respectively. For the Euro area as a whole, the gain in employment and output would be around 1.5 percent.

Let us now look at the magnitude of the spillovers under the different types of reforms. Although the response of foreign output is positively correlated with the domestic response, it is very small is magnitude. Across all reforms, the relative change in per capita foreign output is roughly one tenth of the corresponding home output change in the long run. The spillover in consumption, however, is much more pronounced. Changes in foreign per capita consumption following any home policy reform are nearly 60 percent of the change in longrun consumption in the home country, i.e. six times more than the spillover on output.

The reason for this large difference between consumption and output spillover is that while output only increases indirectly via the demand from foreign consumption and home imports, the favorable terms of trade development and the perfect risk sharing on financial market directly boost foreign consumption immediately. Also, output increases only slowly since the rise in terms of trade initially triggers a negative substitution effect away from foreign goods. Foreign consumers, on the other hand, take into account the permanent positive wealth and risk sharing effect, and so adjust their consumption immediately to this higher permanent wealth to smooth the consumption path.

Investment in country 2 initially drops slightly in the first quarters following an expansionary policy in country 1due to the low savings, and the transfer of resources to the more productive home economy. However, as the terms of trade appreciate in country 2 , the real return on investment rises gradually and so does the level of investment. In the long run, the change in aggregate investment in country 2 amounts to almost one quarter of the change in investment at home. Spillover effects on employment are positive, but smaller compared to all the other variables. The reason for this is the opposite wage dynamics in the two economies triggered by the policy as discussed above for the case of the average tax cut. The aggregate employment change in the rest of Euro area is only four percent of the change in Germany. 
To sum up, while domestic labor market reforms have the most pronounced effect on employment, and the least effect on consumption at home, the ranking is reversed for the spillover effect abroad. The reason for this is that consumption reacts to Euro area-wide wealth, which is shared through financial markets, and so home consumers only get to enjoy part of their productivity gain. Employment, on the other hand, responds to national labor costs, and so adjusts directly to wage changes. In the robustness check below, we will show that the assumption of perfect financial market is not decisive for these results. In fact, under an imperfect financial market, all results are qualitatively unchanged since the terms of trade still lead to the asymmetric wealth effect that acts like an insurance mechanism. ${ }^{18}$

\section{E. Relaxing the Perfect Financial Market Assumption}

To see how the perfect insurance market influences the model results, we now let financial markets be imperfect, so that agents across the two countries can only trade a non-contingent bond that pays one unit of good $a$ in each state of the next period. To assure stationarity of the wealth distribution in steady state, we introduce a bond holding cost for agents in country 1. The budget constraint for the representative household in country 1 now becomes:

$C_{1 t}+I_{1 t}+q_{1 t}^{a} \frac{Q_{t}}{\left(1-\Gamma_{B, t}\right)} B_{1, t+1}=n_{1 t} w_{1 t}\left(1-\tau_{1 t}\right)+r_{1 t} K_{1 t}+T R_{1 t}+\Pi_{1 t}+\left(1-n_{1 t}\right) U B_{1 t}+q_{1 t}^{a} B_{1 t}$

where $B_{t+1}$ denotes the quantity and $Q_{t}$ the price (in terms of good a) of a bond that is bought in period $t$ in country 1 . The bond holding cost depends positively on the ratio of bond holding to national GDP:

$$
\Gamma_{B, t}=\gamma_{B}\left[\exp \left(\frac{q_{1 t}^{a} B_{1 t}}{Y_{1 t}}\right)-1\right]
$$

The budget constraint for country 2 is analogous and the bond market clears at the global level, i.e. $s B_{1 t}+(1-s) B_{2 t}=0$. Figure 4 compares the model simulation to the same tax reform - an average tax cut of 3\%-under complete and incomplete financial markets. As already anticipated, the model results do not change in any significant way. Absent perfect insurance, consumption is less positively correlated across countries. In fact, agents in country 2 still consume more than before the reform, but only due to the positive wealth effect. Agents in country 1, on the other hand, get to consume more of their output than under perfect risk sharing. As higher consumption in country 1 triggers higher demand for the $a$ good (due to home bias), the terms of trade depreciate less than under complete markets. This, in turn, allows for a higher real return to capital and hence, a higher investment demand in country 1 . However, apart from these small quantitative differences, all qualitative results

\footnotetext{
${ }^{18}$ This is a well known result by Cole and Obstfeld (1991)
} 
from the complete markets model hold. This is due to the fact that the positive wealth effect from the terms of trade appreciation acts like an insurance mechanism for agents in country 2 even without the perfect financial market. Note that also due to the higher consumption differential under imperfect markets, trade balance, and the net foreign asset position (last row in Figure 4) initially deteriorate as agents in country 1 borrow to finance their high consumption and repay gradually with higher output.

\section{NOMINAL RIGIDITIES AND MONETARY POLICY}

In this section, the benchmark model is enriched with the following nominal rigidities: Calvo price-setting with partial inflation indexation in the intermediate goods sector. ${ }^{19}$ In such a setting, not only the relative prices, but also the change in CPI (inflation) in each country has allocative effects. In particular, intermediate goods firms are allowed to reoptimize their price with probability $1-\xi_{p}$. Firms which are not allowed to reoptimize index their price partially to the last period's inflation rate by an indexation factor ${ }^{\gamma_{p}<1}$. It can be shown that in the log-linearized version of the model, the producer inflation rate in country 1 behaves according to a backward- and forward-looking New-Keynesian Phillips curve, and reacts to the current producer real marginal costs as follows:

$p_{t}^{a}=\frac{b}{1+b g_{p}} E_{t} p_{t}^{a}+\frac{g_{p}}{1+b g_{p}} p_{t-1}^{a}+k\left[q r_{1, t}+(1-q) w_{1, t}+(1-w) T o T\right]$

The producer inflation rate in country 2 is analogous, but with the terms of trade reducing the producer marginal costs, instead. Moreover, the two countries are linked by a single interest rate rule set by a common central bank. Since we assume that the two countries form a monetary union, the common central bank reacts to a union-wide measure of inflation and output growth while smoothing the nominal interest rate according to the following Taylor rule:

$$
\hat{R}_{t}=r_{i} \hat{R}_{t-1}+\left(1-r_{i}\right)\left(g_{p} \hat{p}_{t}^{u}+g_{y} \hat{y}_{t}^{u}\right)
$$

The union-wide inflation rate and output growth are taken as the population-weighted average of the country-specific CPI inflation rates and output growth. When this economy is simulated under the same policy reform as before, the domestic response is dampened, whereas the spillover effects abroad are magnified in the short run compared to the flexible price setting (Figure 5). This asymmetric development is due to the opposite response of each country's consumption-based real interest rate (last row of Figure 5):

In country 1 , the lower labor costs due to lower wage demand reduce firms' real marginal costs. As firms can only gradually adjust their prices, this leads to a decline in inflation in

\footnotetext{
${ }^{19}$ The nominal extension follows the closed economy model as in Smets and Wouters (2003).
} 
country 1 . The central bank, reacting to this disinflationary pressure according to a Taylor rule, responds with a nominal interest rate cut. In the initial periods however, lower inflation still leads to a higher real interest rate in country 1 . Here, the nominal rate cut is not sufficient to counter the disinflationary pressure on real interest rates. This contractionary force initially dampens demand, and hence the expansion of output and employment in country 1.

In country 2 , the consumption price inflation reacts less to the lower labor costs in country 1 (due to home bias), while the lower nominal interest rate feeds through completely to lower the real interest rate. As a result, the real interest rate in country 2 is initially lower than in the flexible price model. This expansionary force stimulates output and demand in country 2 , so that the short term spillover effects overshoot their long term level. In the long run, prices adjust completely, and the flexible price (benchmark) allocation is achieved.

With regards to the role of labor unions, nominal rigidities tend to reinforce the real rigidity induced by labor unions in country 1 , so that the response to tax reform is further dampened (in the short run) when compared to the competitive market case. For the trading partner in the monetary union (country 2), nominal rigidities tend to magnify the positive spillover response in the short run compared to the competitive case. As a result, the relative magnitude of spillover effects in the short run is much higher than in the flexible price model. Specifically, in the first period, the relative increase in output and employment in 2 is now one quarter of the increase in country 1 , as opposed to one hundredth as in the flexible price model.

\section{Conclusion}

This paper analyzes the macroeconomic responses to labor market reforms similar to those carried out in Germany in the recent years. It uses a dynamic open economy model to assess the domestic as well as the spillover effects of such reforms resulting from trade and financial market linkages. The introduction of labor unions with an explicit wage bargaining mechanism in the dynamic open economy setting is the main new contribution of the paper. Moreover, the paper highlights the importance of changes in the tax wedge, tax structure, and welfare benefits for economic activity and international relative prices. The paper also models the interaction of the labor market frictions with nominal rigidity and the common monetary policy.

The findings indicate that reforms in the area of labor taxation and welfare benefits, as well as reforms in the collective bargaining system, have strong positive effects on the domestic economy, positive, albeit limited, effects on foreign output/employment (if no nominal rigidities are considered), and sizable positive spillovers on foreign consumption and investment. Compared to the case of competitive labor markets, the domestic effects of the reforms are dampened, and the foreign spillovers are strengthened by the existence of labor unions. In particular, they operates through the real wage rigidity induced by unions' rent seeking, and through the absence of wealth effect on individual labor supply. This 
dampening and magnification mechanism is further strengthened by the existence of nominal rigidities, and the ensuing reaction of a common monetary policy in the short run.

In light of these theoretical results, we can expect labor market reforms such as those carried out in Germany to have gradual expansionary effects on the national economy, and significant positive spillover effect on the other members of the Euro monetary union, especially in the first quarters following the reform. This supports the view in favor of labor market and other social policy reforms coordination. In fact, by carrying out reforms simultaneously, and in a coordinated fashion, all countries in the monetary union can benefit from internalizing these positive externalities, and, hence, achieve higher efficiency. ${ }^{20}$

\footnotetext{
${ }^{20}$ A similar point has been put forward by Bertola (2006).
} 
Figure 1. Dynamic Responses of Domestic (left) and Foreign (right) Variables Following a Cut in Average Tax by $3 \%$, time in quarters

\section{- Dynamic response to gradual decrease of tau by $3 \%$}
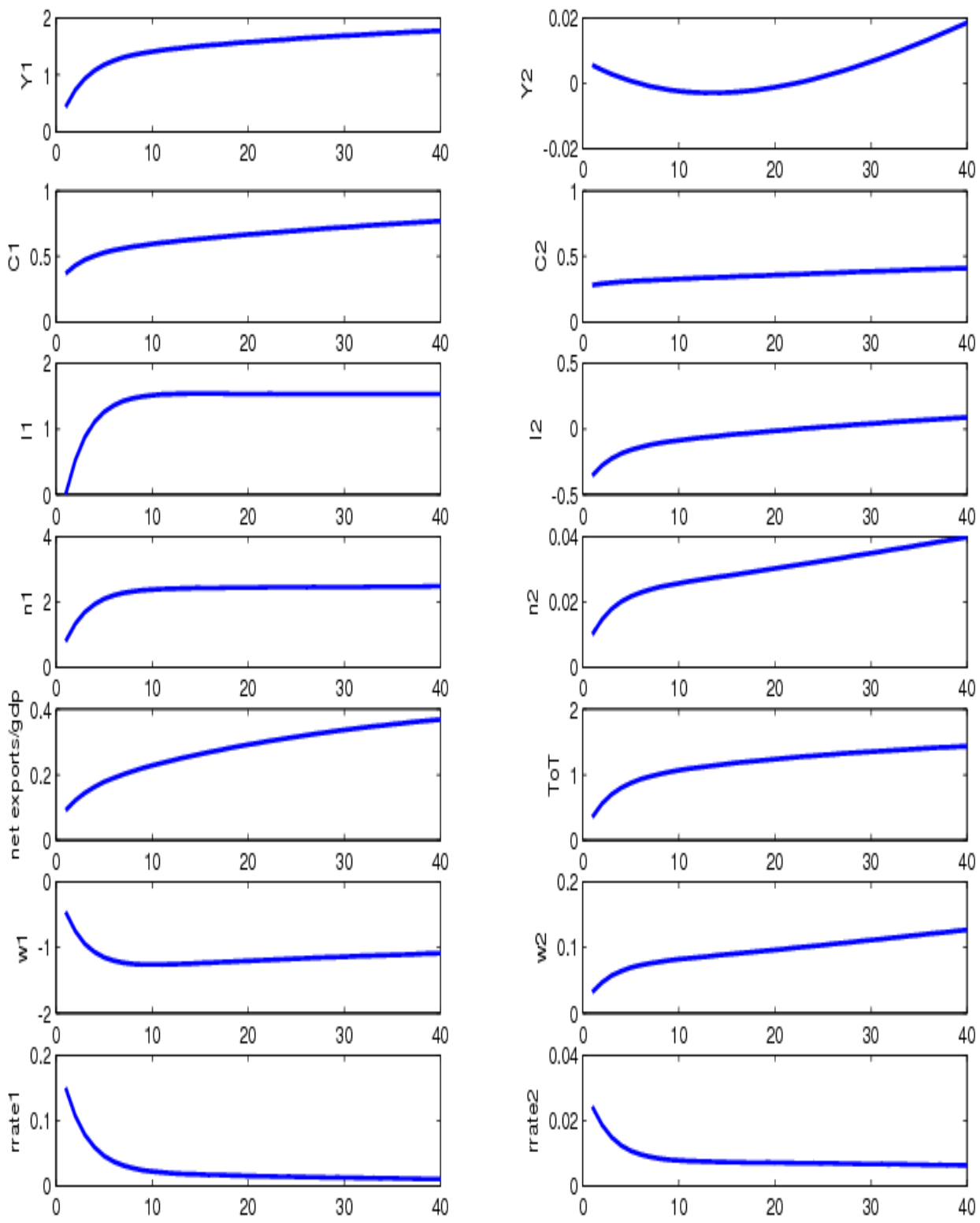
Figure 2a. Comparison output and absorption
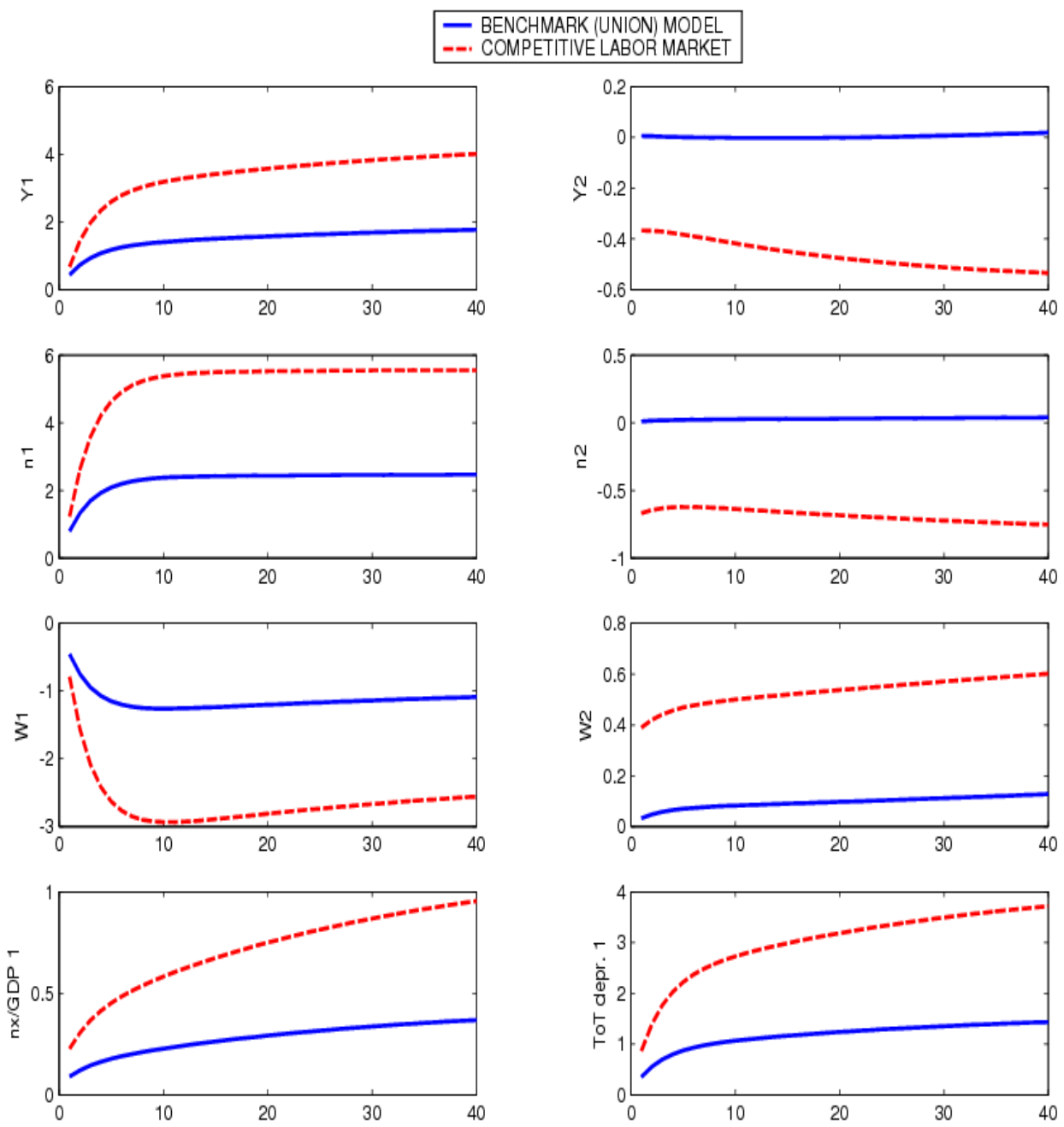
Figure 2b. Comparison of Response to $3 \%$ Tax Cut Under Unionized and Competitive Labor Market (cont.)
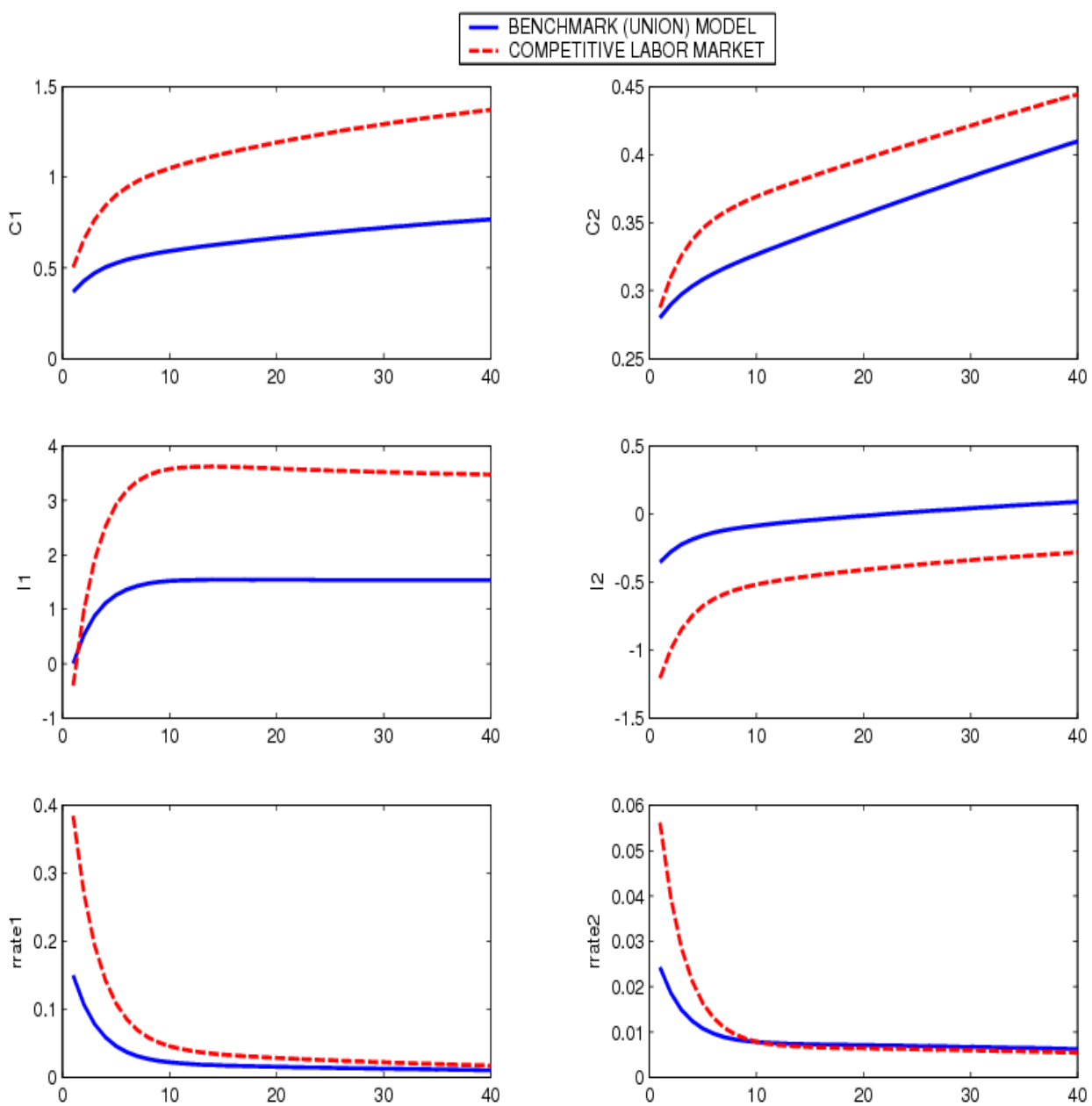
Figure 3. Response of Domestic (left column) and Foreign (right column) Variables to an Average Tax Cut of 3\% in Country 1, Under Benchmark and Completely Closed Economies

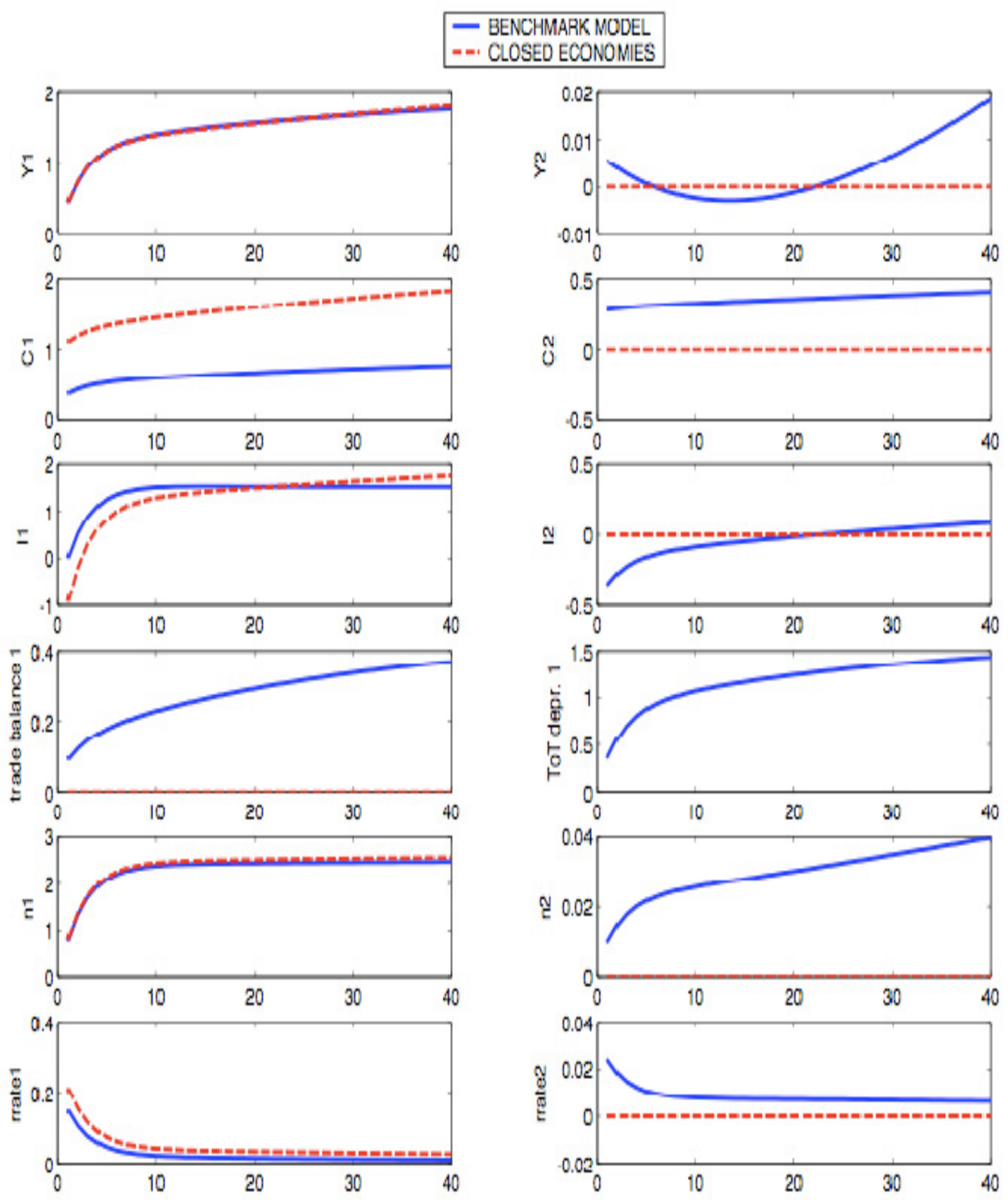


Figure 4. Responses of Domestic (left column) and Foreign (right column) Variables to an Average Tax Cut of 3\% in Country 1, Under Benchmark and Incomplete Financial Markets
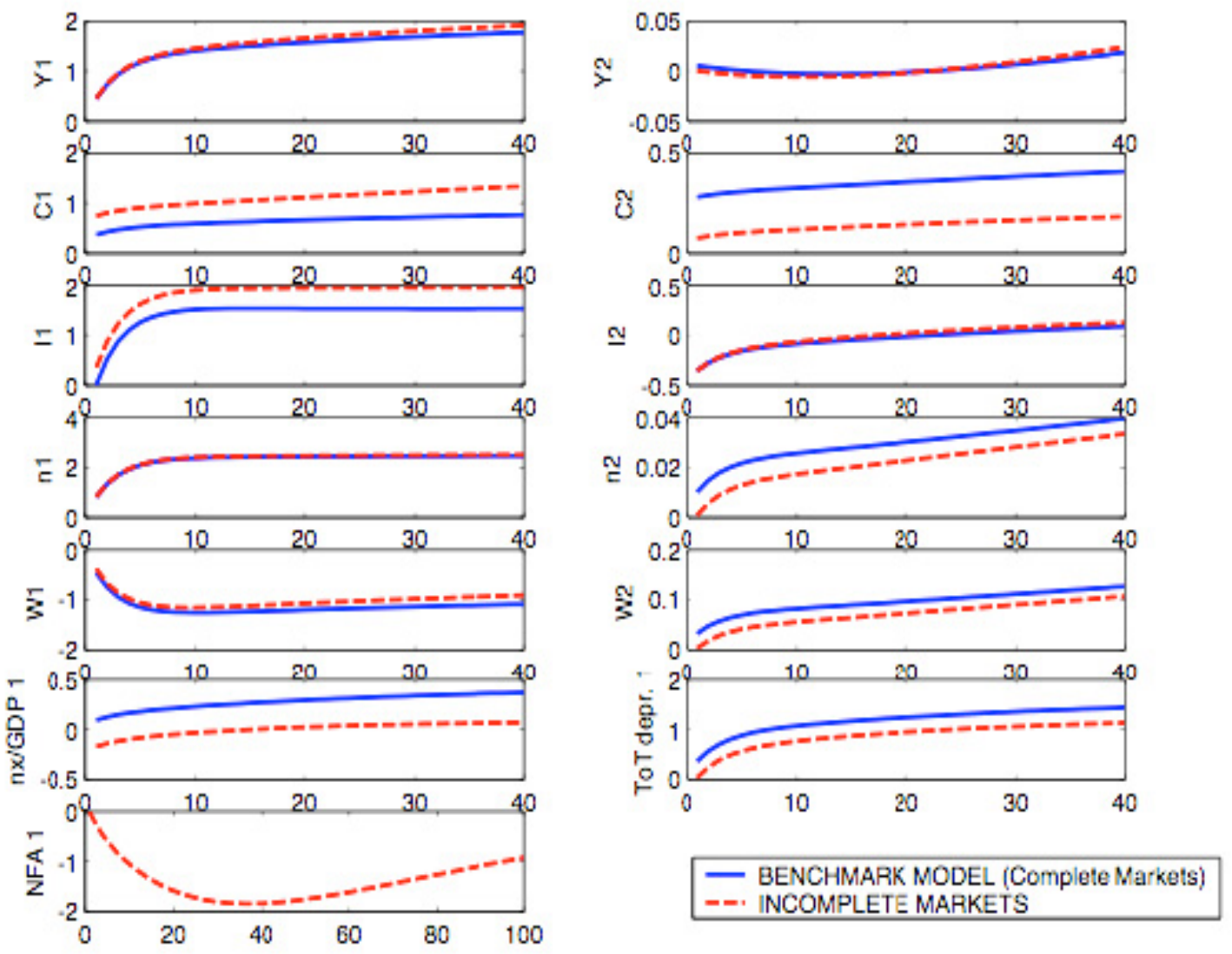
Figure 5. Responses of Domestic (left column) and Foreign (right column) Variables to an Average Tax Cut of 3\% in Country 1, Under Benchmark and Sticky Prices cum Monetary Union

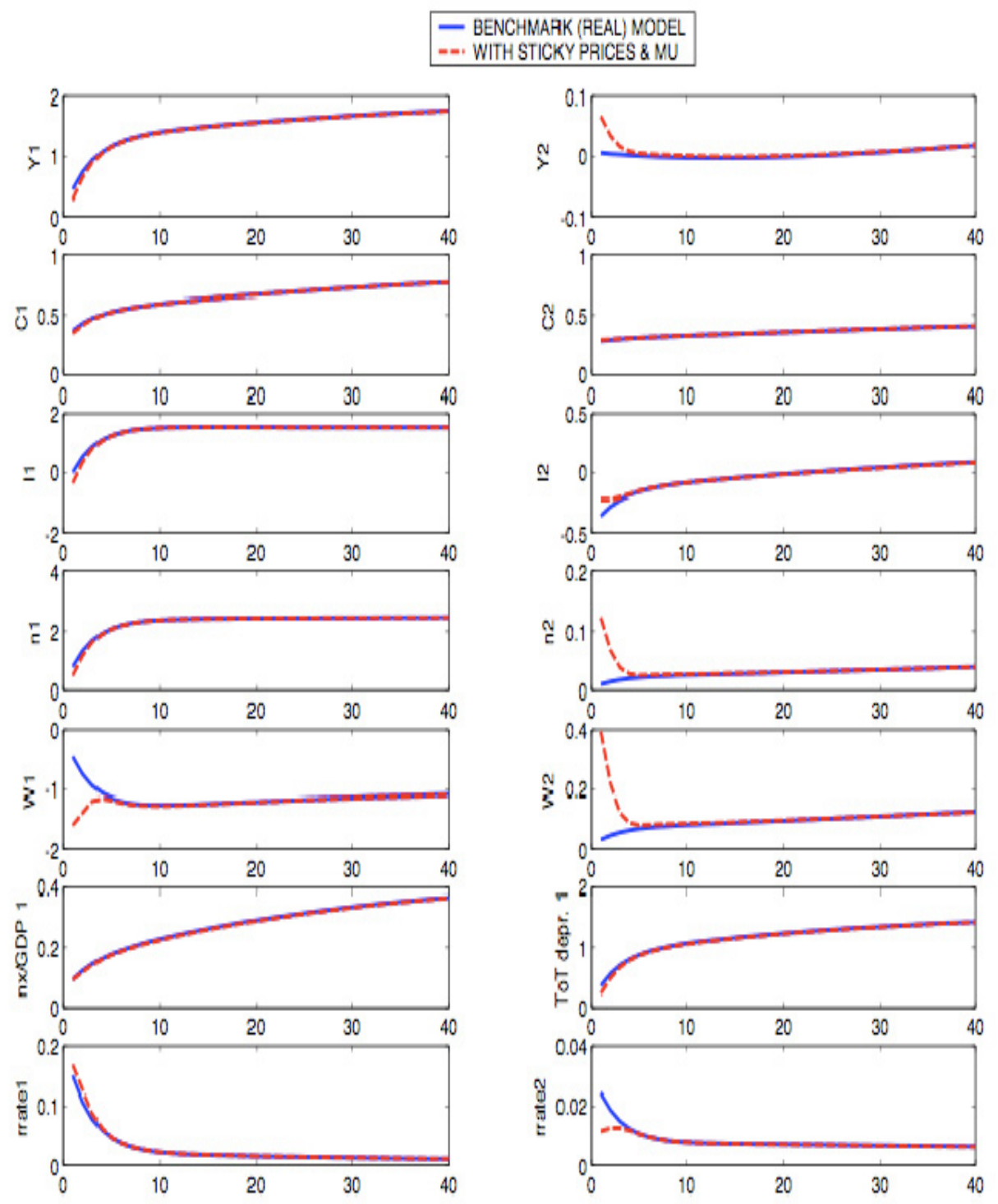




\section{REFERENCES}

Alesina, A., and R. Perotti (1997), “The welfare state and competitiveness," American Economic Review 87, pp. 921-939

Anderson, G. and G. Moore (1985), “A linear algebraic procedure for solving linear perfect foresight models", Economics Letters 17(3), pp. 247-252

Ardagna, S. (2007), "Fiscal policy in unionized labor markets", Journal of Economic Dynamics \& Control 31, pp. 1498-1534

Arvanitis , A. V. and A. Mikkola (1996), "Asset market structure and international trade dynamics”, American Economic Review, Vol. 86, No. 2, Papers and Proceedings , pp. 6770

Backus, D.K., P.J. Kehoe and F.E. Kydland (1994), "Dynamics of the trade balance and the terms of trade: the J-curve?", American Economic Review 84(1), pp. 84-103

Bayoumi, T., D. Laxton, and P. Pesenti, 2004, "Benefits and Spillovers of Greater Competition in Europe: A Macroeconomic Assessment,” ECB Working Paper 341

Baxter, M. (1995), "International trade and business cycles" in G.Grossman and K.Rogoff (eds.), Handbook of International Economics, Volume 3, pp. 1801-1864

Beetsma, R. , M. Giuliodori, and F. Klaasen (2006), "Trade spill-overs of fiscal policy in the European Union: a panel analysis”, Economic Policy October 2006, pp. 639-687

Bertola, G. (2006), "Social and Labor Market Policies in a Growing EU” Swedish Economic Policy Review 13:1 (Spring 2006), pp.189-232

Bertola, G. (2007), “The economics and politics of social policy in Europe's EMU”, Web essay at: http://www.eurointelligence.com/, 29th March 2007.

Blanchard, O.J. and C.M. Kahn (1980), “The Solution of Linear Difference Models under Rational Expectations”, Econometrica, Vol. 48, No. 5 , pp. 1305-1311

Blos, K. and H. Rudolph (2005), "Simulationsrechnungen zum Arbeitslosengeld II: Verlierer, aber auch Gewinner”, IAB Kurzbericht Nr. 17/2005

Botero, J., S. Djankov, R. La Porta, F. López de Silanes and A. Shleifer (2004), The Regulation of Labor, Quarterly Journal of Economics 119, pp. 1339-1382. 
Chari, V. V., P. J. Kehoe and E.R. McGrattan (2002), "Can Sticky Price Models Generate Volatile and Persistent Real Exchange Rates?", Review of Economic Studies, Vol. 69, No. 3, pp. 533-563

Coenen, G., P. McAdam and R. Straub (2007), “Tax Reform and Labour-Market Performance in the Euro Area: A Simulation-Based Analysis Using the New Area-Wide Model", Journal of Economic Dynamics \& Control, forthcoming

Cole, H.L. and M. Obstfeld (1991), "Commodity Trade and International Risk Sharing: Ho much do Financial Markets matter?", Journal of Monetary Economics, 28(1), pp. 3-24

Corsetti, G. and G. Müller (2006), "Twin deficits: squaring theory, evidence and common sense”, Economic Policy October 2006, pp. 597-638

Dumont, M., G. Rayp, and P. Willemé (2005), "Does internationalization affect union bargaining power? An empirical study for 5 European countries," Oxford Economic Papers, Vol 58, pp. 77-102

Erceg, C., L. Guerrieri and C. Gust (2006), "SIGMA: A New Open Economy Model for Policy Analysis", International Journal of Central Banking, vol. 2 (March 2006), pp. 1-50

Erceg, C., C. Gust and D. Lopez-Salido (2007), "The Transmission of Domestic Shocks in Open Economies”, Working Paper, August 2007

Erceg, C. J. \& D. W. Henderson and A.T. Levin (2000), “Optimal monetary policy with staggered wage and price contracts" Journal of Monetary Economics, Elsevier, vol. 46(2), pp. $281-313$

Faini, R. (2006), "Fiscal policy and interest rates in Europe", Economic Policy 47, pp. 435480.

Hansen, G. (1985), "Indivisible Labor and the business cycle", Journal of Monetary Economics 16, pp. 309-327

Heathcote, J. and F. Perri (2002), "Financial Autarky and International Business Cycles", Journal of Monetary Economics 49(3), pp. 601-627

Langedijk, S. and W. Roeger (2007), “Adjustment in EMU: A model-based analysis of country experience", European Economy: Economic Papers 274 
Lockwood, B. and A. Manning (1993), "Wage setting and the tax system theory and evidence for the United Kingdom" Journal of Public Economics, Elsevier, vol. 52(1), pp. $1-29$

Lubik, T. and F. Schorfheide (2005), “A Bayesian Look at New Open Economy Macroeconomics", NBER Macroeconomics Annual 2005, edited by M. Gertler and K. Rogoff

Maffezzoli, M. (2001), "Non-Walrasian Labor Markets and Real Business Cycles", Review of Economic Dynamics 4, pp. 860-892

Pissarides, C. A. (1998) "The impact of employment tax cuts on unemployment and wages; The role of unemployment benefits and tax structure", European Economic Review, Elsevier, vol. 42(1), pages 155-183

OECD, 2004, Benefits and Wages

OECD, 2006, "Employment Outlook"

Prescott, E.C. (2002), "Prosperity and Depression", American Economic Review, Volume 92, Number 2 , pp. 1-15

Schneider, K. (2005), "Union wage setting and progressive income taxation with heterogeneous labor: theory and evidence from the German income tax reforms 19861990”, Labour Economics, Elsevier, vol. 12(2), pp. 205-222

Smets, F. and R. Wouters (2003), "An Estimated Dynamic Stochastic General Equilibrium Model of the Euro Area", Journal of the European Economic Association 1(5), pp. 11231175

Van der Ploeg, F. (2006), "Rolling back the public sector: differential effects on employment, investment and growth", Oxford Economic Papers 58 (1), pp. 103-122

Zanetti, F. (2007), "A non-Walrasian labor market in a monetary model of the business cycle", Journal of Economic Dynamics \& Control forthcoming. 


\begin{abstract}
APPENDIX
Varying the elasticity of substitution

Most model results are qualitatively robust to parameter values. Along the adjustment path, however, the intratemporal elasticity of substitution $\sigma$ for traded goods plays an important role for the policy spillover on country 2. Figure 6 illustrates responses of key variables to the same policy experiment as in section 2, but with varying values of $\sigma$. The higher $\sigma$, i.e. the stronger relative demand adjusts to relative price change, the lower the terms of trade depreciation for country 1 following a tax cut.
\end{abstract}

For a sufficiently high elasticity of substitution such as $\sigma=2.5$, the spillover on output in country 2 is persistently negative, as the negative substitution effect dominates the positive wealth effect. Consequently, the investment response is also persistently negative, as lower output implies lower savings, further exacerbated by the lower return to capital due to lower terms of trade compared to the benchmark. All other variables in country 2 still respond positively, but with a lower magnitude given a higher $\sigma$. Only consumption increases even more in country 2 (and less in country 1 ) due to perfect risk sharing. In the long run, however, our benchmark results are qualitatively unchanged. ${ }^{21}$

For a lower elasticity of substitution (red lines in Figure 6), our benchmark results regarding the response of aggregate quantities are actually reinforced. This is due to the higher terms of trade appreciation of country 2 which leads to higher (positive) spillover in output, investment and employment. At the same time, lower $\sigma$ implies lower consumption spillover through perfect risk sharing. However, the new insight from section 4.2 reveals that labor market unionization works in the same direction as a low elasticity of substitution, as far as the quantity reactions are concerned. Unionization implies a dampening effect at home, and a positive spillover effect through a more rigid wage, i.e. supply response, and, hence, lower terms of trade depreciation, while a lower elasticity of substitution leads to the same domestic dampening, and positive spillover, through a more rigid demand response, and, hence, higher terms of trade depreciation. This represents a potential source for misspecification for parameter estimates based on models with competitive labor markets which are common in the literature if, in fact, union bargaining is present.

\footnotetext{
${ }^{21}$ Such high values for $\sigma$ are usually not found in empirical estimates. Rather, the elasticity of substitution is mostly estimated to be even lower than in our calibration (see e.g. Lubik and Schorfheide 2005, Heathcote and Perri 2002).
} 
Appendix Figure. Varying the Intratemporal Elasticity of Substitution: Dynamic Responses of Domestic (left) and Foreign (right) Variables Following a Cut in Average Tax by $3 \%$, time in quarters

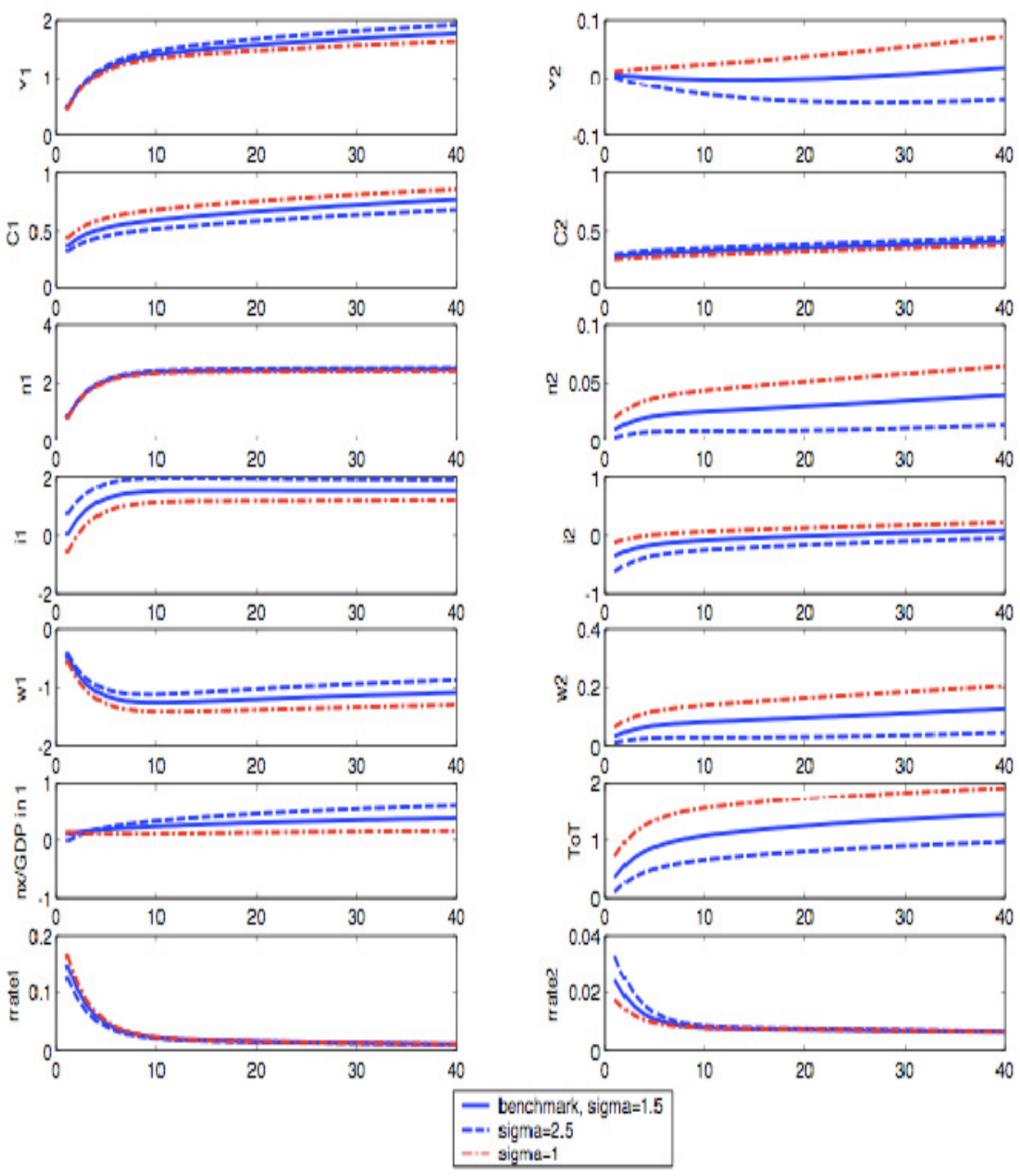

